\title{
ON TIME AND FORM IN WHITMAN'S "CROSSING BROOKLYN FERRY"
}

\author{
Paul A. Orlov
}

IN THE PREFACE to the 1855 edition of Leaves of Grass, Walt Whitman speaks of the poet as a "seer" whose creative and imaginative breath "dilates" any "thing that was before thought small ... with the grandeur and life of the universe." One of the recurring phrases in his poem, "Crossing Brooklyn Ferry," is "great and small," and Whitman uses his poetic imagination to transform what might have been his "smallest sights and hearings" into the "glories" of the transcendental experience which is the poem. ${ }^{2}$ For initially, the poem concerns the poet's small personal moment on the ferry, but at once, as Howard Waskow has noted, "the physical act of 'crossing Brooklyn ferry' is analogous to the crossings achieved by the imagination" 3 in its explorations of experience. And those imaginative crossings pass through the barriers of time and space, thus filling the given moment with "the grandeur and life of the universe"-and of eternity.

Although critics have sometimes claimed that Whitman's verse generally suffers from a looseness of form ${ }^{4}$ it is precisely through a strategic and careful poetic form that he achieves in this poem a crossing that involves poet and reader alike in a timeless voyage of being. Another statement in the 1855 Preface adumbrates the nature of the formal technique discoverable in his best verse:

Without effort and without exposing in the least how it is done the greatest poet brings the spirit of any or all events and passions and scenes and persons some more and some less to bear on your individual character as you hear or read. To do this well is to compete with the laws that pursue and follow time. ... Past and present and future are not disjoined but joined. The greatest poet forms the consistence of what is to be from what has been and is. . . He learns the lesson ... he places himself where the future becomes present. ${ }^{5}$

This theory is at the heart of the created shape of "Crossing Brooklyn Ferry," a poem whose central metaphor manifests the merging of present and future as Whitman uses the correspondence between time and poetic form to assure that we will share with him the "lesson" of transcendence.

At the start of the poem, Whitman generally conveys a sense of both the immediate moment and the future moments into which it will expand. The "flood-tide below" that the poet sees "face to face" in the opening line is not only the river, which will itself flow through the poem timelessly, but also time itself, the surface upon which the poem's quintessential "crossing" takes 
place. While the poet's literal and imaginative eyes are turned toward the sky, he gives us another image temporarily tied to the moment that will soon, as well, illuminate the future - that of the "sun there half an hour high." As the focus turns toward the "crowds of men and women," who are of such interest to the poet, Whitman explicitly introduces the idea of the parallelism between present and future, the idea obliquely suggested in the first two lines. For the crowds of people, whom we presume at first to be those the poet sees in the scene he is actually watching, are at once divided into two ferry-boat crowds: one is that literal, present crowd, but the other is an imagined one in the future of "years hence." And these last lines of the poem's first section, introducing the time levels which Whitman will elaborate, also illustrate the idea of people of different times sharing experiences and places fundamentally the same-the idea crucial to the "crossing" ahead.

In the opening section, we as readers are just that and find nothing unconventional about the time scheme: those who "shall cross from shore to shore years hence" are still only in the poet's meditations, and both the poet and his thoughts are in what seem a normal, fixed present. Section 2, however, begins to move us precipitately toward the sense of that eternal moment which the poem itself both describes and embodies. Lines 6-12 tell us, in a preliminary way, what the river and sky and ferry-boat mean to the mind of the poet. They are manifestations of the "things" from which he draws - for his imagination - "impalpable sustenance." In the context of the poem's vision, these particular things, and especially the ferry-boat of Whitman's literal crossing, are the "similitudes of the past and those of the future" (1. 8). It is through the medium of these "similitudes," these counterparts of place or experience (such as the scene on and around the ferry combined with the ferry crossing itself), that past and future - the original present of Section 1 and the new present of Section 3-start to attain an overlapping unity. These "similitudes" are a landscape within which the poet meditates and which the future voyagers upon whom he meditates will share.

As John Lynen puts it, "The transcendental voyaging by which [Whitman] comes to share the experience of future generations and of his reader, however distant in time, develops directly from the objects before him." ${ }^{\prime} \mathrm{It}$ is those objects of the environment that make it possible for him and everyone else to be "disintegrated ... yet part of the scheme" (1. 7), separate and yet one. Thus, in the terms of the 1855 Preface, it is the ferry and all the things seen from it which enable the poet to "place himself where the future becomes present," for they comprise the setting within which that time transformation occurs. And the consequence of this process of escaping from time barriers through unifying perceptions and experience is (or will be) the conversion of the poet's "smallest sights and hearings" into "the glories strung like beads" upon them (1. 9).

The image of the string of beads aptly represents in miniature the 
paradoxical perspective on time of the poem as a whole. Initially, of course, the image suggests the continuum of time, as if within the poet's "present" of perceptions and experiences; yet the image suggests more essentially that the perceptions and experiences of the poem exist, in effect, at every point in time, as "glories" of the phenomena of life common to people at any point upon the string. The poetic consciousness alters a conventional string or line of time in this manner, for the "similitudes" (the beads) are common to people of all points in time just as the sky (one of the beads) is to people of all points in space in the world. (This image of the sky as a continuity over conventional space-time barriers is one I will return to.) So we now recognize the direction of the imaginative crossing, and understand the sense in which "the current" (of time) is "rushing so swiftly" and carrying the poet far away in its flux (1.10), making possible firm "ties between" him and the "others that are to follow" him in his crossing (1. 11).

From this point in the poem forward, Whitman will give us "proofs" to confirm the reality of those "ties" in such a way that those "others" of the literal future approach his presence in the imaginative present. In the second half of Section 2, just as the poet moves from a general explanation of the "similitudes" to specific aspects of them, so does he turn his focus from a merely theoretical awareness of the "others that are to follow" to views of those "others" and what they will experience. At this point, the "others" - including ourselves - are still part of the future which the poet is mentally conceiving from his starting position in time. For when he says, "Others will enter the gates of the ferry and cross from shore to shore, / Others will watch the run of the flood-tide" and so on, we understand the counterpart action at each point which he himself $i s$ performing. This recognition of counterparts ("similitudes") as well as the still clear division in time (marked by "will" as repeated verb auxiliary and phrases such as "fifty years hence") reminds us that the poet is not at all denying time distinctions nor eliminating the fact of being "disintegrated" to facilitate his illumination of unity in "the scheme" of life. Yet the references to that temporal dis-integration of "others" from himself remind us of the poet's need to compete somehow with time in order to merge our spirits with his in a credible-which is to say subtly effective-manner. Thus almost imperceptibly, Whitman begins to use a device of form here (in 11.15-19) that softens the transition through time-the repetition of a perceived part of the landscape or of a phrase, in a different time context from that in which it first appeared in the poem. At this point, for example, he speaks of the sun's being "half an hour high" during the crossing of the "others" fifty or more years hence, just as it is (was) in his crossing at the start of the poem, in the original present that will soon seem past. This phrase helps to move the flow of what is distinctly future in Section 2 into what is suddenly experienced as a new present in the poem's third part.

Since Section 2 ends with not only the repeated image but also the motif 
of the time-river's unending flow of continuous states ("the pouring-in of the flood-tide, the falling-back to the sea of the ebb-tide"), it is quite justifiable for Section 3 to begin with the assertion which is, essentially, the theme of the poem: "It avails not, time nor place-distance avails not" (1.20). The ebb and flow of the water reminds us that it is from an experiential viewpoint that time and distance "avail not," that common perceptions and experiences make those who are otherwise "disintegrated" united in the "ties" of a voyage which obliterates the temporal and spatial barriers. We see the basis on which the poet makes his transcendental assertion, which in turn enables him to announce, "I am with you, you men and women of a generation, or ever so many generations hence." But we may still be skeptical about how much the poet's crossing is also our own, and in this third section, Whitman instantly sets about removing any doubts we have. The method he pursues in doing so is a clever stylistic one: he parallels his shift in time context (in which he is with us now in a new present making his "present" the past) with a striking shift in emphasis from himself to us as participants in the crossing experience. The opening lines of the section, with their "just as" expressions, put us in the central role (in keeping with the idea that it is our present now being described), for in each case the poet alludes to his past actions and perceptions only to indicate his understanding of ours of the moment. The future-changeably defined as fifty years hence or any time, and therefore all futurity - has become the new present; the present has become the past, conveyed only in reflective past-tense statements such as "so I felt" that seem secondary to the present-tense verbs applied to the journeying of the "others" now addressed directly as "you."

The direct addressing of the reader, combined with the stress upon his (that is, our) experiences of the landscape, serves to create the impression that the poet is truly with us, notwithstanding the divisions of time and space. Whitman uses this form of expression to involve us necessarily with him and his own (now past) experiences. The corresponding moments and sensations he chooses in order to create this effect are true to his own previously introduced setting on the ferry, and yet simultaneously so common to life itself as to be inescapable. He risks no strain upon our sense of unity and involvement when he speaks of our feelings in looking at the sky and river, for example, for all of us, at any point in time or space we can imagine, will have such perceptions and feelings. Thus the poet begins convincing his readers that "it avails not, time nor place," by showing that material separations and the differences of personal situations dissolve-when exposed to the element of shared moments of seeing and being -into a transcendental state of spiritual unity and common human identity.

Part of what this awareness of being "disintegrated yet part of the scheme" means, here and throughout the poem, is that time and space distinctions must be recognized and in constant focus, paradoxically enough, in 
order to be hidden and blurred. This idea is conveyed by the use of repeated images (such as the "sun half an hour high") which reflect it by producing an impression of being simultaneously at two points in time some fifty or more years apart. Just slightly different from that impression is one based on being simultaneously static and in motion, a variant of the sense of being temporally fixed and yet transcending time. These paradoxical ideals, basic to the theme of the poem, are important spatially as well since space and time are connected by the very sense that the literal ferry crossing is also the imaginative crossing through the dimensions. All of these connections are clarified through the symbolic as well as literal meanings of line 25 early in the third section: "Just as you stand and lean on the rail, yet hurry with the swift current, I stood yet was hurried. . . ." Not only does this fact of boat travel mirror the idea of being spatially static and yet in motion, but also it acts as a fitting repeated image to tie our experience to the poet's, connecting Section 1 to this section. So there is an ingenious device at work here in which the description of the experience of leaning on the rail, motionless, as the ferry moves onward, simultaneously expresses and illustrates the poem's theme, while additionally acting as a link between the old and new "present" in order to prove it. At the start of the poem in the context of that actual present from which his poetic voice issues, Whitman is (was) in the position by the rail which we now occupy, in the context of our present. It is not just that the repetition of this moment and idea is a formal device which renders credible and natural the transcending of time and space. All of the uses of repeated moments of images in the poem are such keys in form to the creation of the timeless crossing. Rather, the special value of this particular form is that it is in all senses an apt proof of the point Whitman must make us feel about our unity with him. And curiously enough, it is a notable stroke of genius in poetic form for the poet to use a readily accepted yet paradoxical fact (that we stand still on a ship while rushing through the "current" of time and space) to reconcile us to his fundamental theme-which is the symbolic, imaginative parallel of that acknowledged fact.

Having established thus far in Section 3 the setting in the new present and the basic correspondence between the present and his past, the poet must succeed, in the remainder of the section, in fully securing our sense of that present, and the shared unity of corresponding experiences. Because he must do this, convincing us firmly that time and place barriers do not "avail" to divide us, the third section is a critical one for the effectiveness of the entire poem. Whitman rises to the occasion in the remainder of the section by using a very interesting technique. As he had theorized in the 1855 Preface that his poetic task must be to involve the reader imperceptibly in a sense of shared experience and immediacy to the poet, so indeed he strives here to achieve this task by keeping the sense of the present vivid for those who live in it, even while he refers to his past. Somehow, in fact, there must be a conceal- 
ment of the poem's natural progression so that "the present will seem to remain the same moment throughout."7 The formal method which Whitman uses now to make his present (now past) and our present remain the same moment throughout in terms of shared experiences is based on syntax and the manipulation of verbs.

Literally, the remainder of the section (11. 27-48) is one elongated sentence packed with a catalogue-like array of the perceptions the poet has made in the past which we presumably share in now. The "sentence" begins "I too many and many a time cross'd the river of old," since all of the shared experiences are built upon the particulars of the ferry crossing in which the poet has imaginatively involved us. In reading or hearing the poem, then, we apply the "I too" to each new aspect of the elaborate thought, as the subject of "watched," "saw," and so on. As the poet uses these past tenses to detail his perceptions, he compellingly implicates us-as the reason for "too"-as having them in the present. Yet the repetition of past tenses, all linked to his own distinct position as an "I," puts the poet in danger of losing his hold upon our sense of involvement, of failing to make our present and his own seem the same moment. And this is why, I would contend, he alters his mode of expression so strikingly in the midst of the catalogue-like sentence.

After the line ("I too") "saw the white sails," etc., Whitman stops using the past-tense verbs at the start of the lines. While it is understood that all that follows connects to the verb "saw" in lines 37-38, we cease to be so conscious of the past and return to a focus upon what seem statements of present scenes. Whitman leads us to this focus upon an ongoing "present" by his subtle introduction into the passage of verbs in the progressive tense group. Using here temporally indeterminate gerunds (such as "the falling of them at sunset") and participial adjectives (such as "the fires . . burning high") in phrases referring to things the poet "saw," Whitman creates a dominant effect conveying the progressive sense, as that past-tense verb fades from our immediate perception into the background of the extended thought. That is, the "-ing" words are words that encourage the impression of process still ongoing even as they (logically and grammatically) fit the past to which the poet refers, for they are meaningful with auxiliaries in the tenses of past, present, or future. Therefore these words, along with phrases which are temporally equivocal when not hinged to the verb "saw" (it is easy to think of "the sailors at work" and so forth not as phrases dependent upon that verb, but rather as flashes of scenes timelessly before us), simultaneously accomplish the task of making Whitman's present and ours seem the same moment, and vivify our shared perceptions. In this connection it is notable that the use of an actual progressive verb makes the title of the poem a grammatical or linguistic parallel of the poem's essential theme: the "crossing" adapts itself to any subject and any tense (the latter with the tacking on of an appropriate auxiliary) as a word, just as it adapts itself, as an experience in this poem, to 
any time or person because of its intrinsically unchanging qualities.

Since Section 3 establishes the new "present" and our unity of experience, it culminates the basic movement in the poem; in the fourth section, the poet brings the aspects of the crossing into summarized momentary stasis.

These and all else were to me the same as they are to you,

I loved well those cities, loved well the stately and rapid river,

The men and women I saw were all near to me,

Others the same-others who look back on me because I look'd forward to them,

(The time will come, though I stop here to-day and to-night.) [11. 49-53]

Here there is a reminder that the past and present are distinct as well as unified. The resolution of the paradox, in a sense, is that the recognition of oneness leads people to look out from their own time perspective toward the other perspective, creating an intersection of visions: "others who look back on me because I look'd forward to them." And this intersecting means that past and present can be different, yet have a "sameness," because each contains "similitudes": containing similitudes to other times, each present contains these other times as aspects of itself, in a world always essentially "realizing the same meaning."

At this point, having made us understand the nature of the eternal moment through shared experiential horizons, the poet has no further need to emphasize details of the external landscape of the crossing. Thus in Sections 5 and 6 of the poem, Whitman evidences the internal facets of the shared journey, giving the moment breadth and depth in what James Gargano has called a "psychological dimension." "The fifth section opens with an echo of the key phrase which began Section 3: "Whatever it is, it avails not-distance avails not, and place avails not." Since "it" refers to the "count" of years, or time, the sense of the line here is just what it was earlier in the poem. And the repetition of this central thematic statement is significant, for it underscores our sense that we are now looking back with the poet just as he was previously looking ahead to us. With reference to the inward phenomena of the mind, quite as much as the phenomena of the outward landscape, we are all unique individuals ("I too had receiv'd identity by my body") and yet unified in certain common bonds of our timeless human condition, the "float forever held in solution" (1. 63;1.62). For as the section stresses, we all feel, as the poet has felt, "the curious abrupt questionings" about the meaning of life "stir within" us (1. 59).

If this section reveals the philosophical ties that bind us all, the next section primarily deals with our common infirmities of nature, not of understanding. In detailing universal moral flaws and character failings, Whitman 
creates a more general "present," an ongoing present of the typical human situation over centuries. To accomplish this poetic purpose, he uses a manner of expression which necessitates our identification with him in truths essential to all times and places: "It is not upon you alone the dark patches fall, / The dark threw its patches down upon me also, / . . Nor is it you alone who know what it is to be evil, / I am he who knew what it was to be evil" (11. 65-66; 69-70). Yet the frailties of our eternal humanity are only part of the psychological dimension of life; so after cataloguing these dark aspects of our "days and haps," the poet reaffirms the positive emotions of laughter, fellowship, and love. In short, on the level of inner being, as on that of outward-looking seeing, we all (like the poet) play "the part that still looks back on the actor or actress" (1. 83). This statement is extremely important, for it indicates that if we have internal and external ties which permit us to transcend time and space, it must be remembered as well that the part we all play, that of human life per se, transcends everyone and flows in eternity. Thus does the "part" look back on-as it moves eternally and they fade in chains of time-all those who fill it. But if this is a reminder of physical mortality, it is countered by constant encouragement toward a sort of spiritual divinity: despite the "abrupt questionings" and the "dark patches," the role of life "is what we make it, as great as we like, / Or as small as we like, or both great and small" (11. 84-85).

Clearly, in taking us with him in an imaginative crossing to recognition of things eternal and man's deepest oneness, Whitman intends to carry us toward the achievement of divine spirit-making the "role . . great." This idea assumes more definite shape when he asks, in Section 8 , "W'hat gods can exceed these that clasp me by the hand . . . ?" (1. 95). As James Gargano has pointed out, "What necessarily follows from the increasing importance inhering in man's least of inspired moments is the Transcendental truth, the divinity of man, for just as time partakes of eternity, mankind is inseparable from God."10 At bottom, Whitman's purpose in this mind-and-spiritexpanding crossing is precisely to put into practice what he "preaches" in a crucial passage of the 1855 Preface:

There will soon be no more priests. Their work is done ... A new order shall arise and they shall be the priests of man, and every man shall be his own priest. The churches built under their umbrage shall be the churches of men and women. Through the divinity of themselves shall the kosmos and the new breed of poets be interpreters of men and women and of all events and things. They shall find their inspiration in real objects today, symptoms of the past and future. . . .11

Indeed, those "real objects" which are his and our inspiration in the crossing, "symptoms of past and future" as well as present, are the "dumb ministers" cited in Section 9. And it is notable that as Section 6 ends, pointing the possibilities of a shared motion toward divinity through poetry, the strands 
of "I" and "you" become "we" - "the role that is what we make it"-emphasizing our oneness in this timeless voyage. For through his technical device of "indirection," Whitman has not just revealed the inspirational "real objects" to us, but rather has enabled us to comprehend their meaningfulness in a crossing aimed at the realm of our highest potentiality.

Even while building toward this sense of comprehensive unity in the role "we" play, in Section 6, the poet uses the past tense. So now, in Section 7, he seizes the moment to assert the other part of the temporal paradox underlying the poem, saying "closer yet I approach you" (1.86). Now straddling the past and present ("I approach you, / . . . I had as much of you"), he evokes fully the sense of intersecting thoughts first conveyed in Section 4: "What thought you have of me now, I had as much of you"; he had looked forward to us as we now look back on him. And yet, nonetheless, our mutual role means that Whitman has truly "consider'd long and seriously of" us before we were born (1. 88). The poem as a realized whole confirms this, validating his boast that he has crossed through all temporal and spatial distances: "Who knows, for all the distance, but I am as good as looking at you now, for all you cannot see me?" (1. 91).

With the two "nows" thus confirmed as simultaneously different and yet the same, the present tense dominates the phrases opening Section 8, reiterating some of our spiritual links and expressing our divinity, as we clasp the poet's hand. Just as the poet earlier looked at the eternal bounds of the world, "flood-tide" and "sun" and sky, 12 so now he "looks" at us, since we share all "which fuses" him into us and fills us with his "meaning" (1. 97). In the ninth and final section of the poem, Whitman recapitulates at length the faces of the eternal landscape and phrases from earlier sections, in order to exhort these "dumb, beautiful ministers" to keep embodying the "old role" and furnishing their "parts toward eternity." They will endure and do so because the poem demonstrates that all "[a]ppearances, now or henceforth" conduce to the awareness emblemized in the halo-like divergent "spokes of light" reflected around our heads "in the sunlit water" $(11.120,116)$. Ultimately transcending time through poetic form, Whitman transforms our "crossing" of Brooklyn ferry into a voyaging of the soul - in order to "accomplish" in the timelessness of art "what the preaching could not" (1. 100).

\section{Pennsylvania State University-Delaware County Campus}

\section{NOTES}

1 Walt Whitman, "Preface 1855," Leaves of Grass, Comprehensive Reader's Edition, ed. Harold W. Blodgett and Sculley Bradley (New York: New York University Press, 1965), p. 713.

2 Quoted from lines 85 and 9 of the poem; all subsequent quotations from the poem are cited parenthetically from the Comprehensive Reader's Edition. 
3 Howard J. Waskow, Whitman: Explorations in Form (Chicago: University of Chicago Press, 1966), p. 216.

4 See, as a notable example of this view, Charles Feidelson, Jr., Symbolism and American Literature (Chicago: University of Chicago Press, 1953), pp. 26-27.

5 Whitman, "Preface," p. 716.

6 John F. Lynen, The Design of the Present: Essays on Time and Form in American Literature (New Haven: Yale University Press, 1969), p. 309.

7 The phrasing is that of Lynen, p. 285, whose reading has helped to shape my own.

8 Lynen, p. 323.

9 James W. Gargano, "Technique in 'Crossing Brooklyn Ferry': The Everlasting Moment," Fournal of English and Germanic Philology, 62 (April 1963), 266.

10 Gargano, p. 268.

11 Whitman, "Preface," p. 727.

12 It seems interesting to me that the poem begins with the images of the "flood-tide" and "sun" in the sky, for the water and sky not only fix the limits of the literal and imaginative worlds within which we find the "dumb beautiful ministers" of eternity and human divinity, but also, in themselves, symbolize the flux and endlessness in form which we mentally discover with Whitman as fundamental qualities of life and the moment of the crossing. While the water is an obvious metaphor for time itself, or, more precisely, indivisible time's current, the sky - with its eternal cycle of "flux" of the rising and falling sun (a recurring image in the poem)-both illustrates and symbolizes the poem's sense. 